\title{
ECONOMIC VALUE ADDED (EVA) AS A PERFORMANCE MEASUREMENT FOR GLCS VS NON-GLCS: EVIDENCE FROM BURSA MALAYSIA
}

\author{
Ismail Issham, Abdul Samad M Fazilah, Yen Siew Hwa, Anton Abdulbasah \\ Kamil, Azli and Meor Azli Ayub*
}

\begin{abstract}
:
EVA is a useful tool for assessing company performance. It combines factors, such as economy, accounting and market information in its assessment. This study employed EVA in an attempt to compare the companies' performances of GLCs (government-linked companies) and non-GLCs. Based on a 4-year pooled panel data of 37 GLCs and 208 non-GLCs, the results show that companies with government as their stakeholders tend to exhibit lower EVA scores than the companies without government stakeholders in Malaysia. Larger size companies were found to have lower EVA values. Companies which have both the characteristics - which are simultaneously large in size and government-owned, tend to be most adversely affected. Thus, any increment in the size of company for GLCs would decrease or destroy the value of the company, and to a greater degree, than companies without government holding.
\end{abstract}

Keywords: economic value added (EVA), government-linked companies (GLCs), performance, size and performance tool

JEL Classification: C11, C23, G14

\section{Introduction}

There are various tools which have been used to predict company performance. Most of these tools tend to conclude that earnings or profit is the main factor in predicting company performance. In this study we emphasize the superiority of a tool called the Economic Value Added (EVA). EVA is one useful tool that could combine factors, such as economy, accounting and market information in its assessment of a company performance. We then apply the EVA in an effort to compare companies' performances of GLCs (government-linked companies) and non-GLCs in Malaysia.

* Ismail Issham, Universiti Sains Malaysia, Penang (issham@usm.my); Abdul Samad M Fazilah, Universiti Malaya, Kuala Lumpur; Yen Siew Hwa, Universiti Sains Malaysia, Penang (shyen@usm.my); Anton Abdulbasah Kamil, Universiti Sains Malaysia, Penang (anton@usm.my); Azli and Meor Azli Ayub, Universiti Sains Malaysia, Penang (azli@usm.my). 


\section{Economic Value Added (EVA)}

Many studies have shown the advantages of using EVA over the traditional tools for assessing corporate performance due to its transparency and capacity to provide more vital information. As an EVA advocate and supporter, Stewart (1994) had suggested that $\mathrm{EVA}^{\mathrm{TM}}$ stands out well from the crowd as the single best measure of wealth creation on a contemporaneous basis and is almost 50 per cent better than its closest accounting-based competitor (accounting measurement tool) in explaining changes in shareholder wealth. Taub (2003) found that the change in EVA explains 35 per cent of the change in Market Value Added (MVA), or seven times more than sales growth, consequently the change in EPS explains only about 3 per cent of the change in MVA. McClenahen (1998) similarly observed that traditional corporate performance measures are being relegated to second-class status as metrics such as EVA becomes management's primary tool and Herzberg (1998) said that there has been widespread adoption of EVA by security analysts.

Gapenski (1996) indicated that EVA ${ }^{\mathrm{TM}}$ measures take into account the cost of equity capital by considering the required rate of return of the investors in calculating the value of the companies. EVA ${ }^{\mathrm{TM}}$ is also the best measure for not-for-profit organisations. EVA is superior to accounting profits as a measure of value creation because it recognises the cost of capital and, hence, the riskiness of a firm's operations (Lehn and Makhija, 1996).

Berry (2003) stated that EVA is ideally suited to publicly traded companies because it deals with the cost of equity for shareholders, as opposed to debt capital. Davidson (2003) argued that while EVA does not only improve banks performance and profitability, its ability to boost stock performance is significant. Further, Burkette and Hedley (1997) claimed in their report that implementing an EVA policy would trigger a company's stock to rise. EVA's long-term performance is not compromised in favour of short-term results and provision at correct incentives for capital allocations (Booth and Rupert, 1997).

EVA is also said to provide better goal congruence than Return on Investment or ROI (Brewer et al. 1999). EVA can eliminate the confusion and conflicts that arise when a firm uses multiple measures, such as EPS, ROI, Return on Equity (ROE) and Net Operating Profit after Tax (NOPAT) (Kudla and Arendt, 2000). EVA can eliminate economic distortions of General Accepted Accounting Practice (GAAP) to focus decisions on real economic results, it enables better assessment of decisions that affect the balance sheet and income statement or trade-offs between each other, and through the use of the capital charge against NOPAT and it covers all aspects of the managerial cycle (Stewart, 1991).

Taub (2003) observes that most tools in industries only concentrate on financial information or accounting information, however, EVA is a combination of market, accounting and economic information giving it a much wider net. By focusing on financial results in economic terms but not accounting terms it provides a significant information value beyond the traditional accounting measures of EPS, Return on Asset (ROA) and ROE (Chen and Dodd, 2001).

EVA $^{\mathrm{TM}}$ is said to have a value-based performance measurement system which has further practical advantages (Stern et al., 1989). It also provides an improvement in 
corporate environmental performance (Epstein and Young, 1998). EVA is more than a measurement of performance; it is a framework for a complete financial management and incentive compensation system (Ehbar, 1998). Drucker (1995) said EVA ${ }^{\text {TM }}$ is a vital measure of total factor productivity and EVA is based on something we have known for a long time, i.e. what we call profits. EVA $^{\mathrm{TM}}$ is regarded as a single, simple measure that gives a real picture of stockholder wealth creation (Tully, 1998). Johnson and Soenen (2003) formulated that one of the benefits of EVA is its simplicity and its easiness to adjust for risk.

An EVA system helps managers to make better investment decisions, to identify opportunities for improvement and to consider the short-term as well as long-term benefits for a company (Stewart, 1994). Furthermore, studies suggest that $\mathrm{EVA}^{\mathrm{TM}}$ is an effective measure of the quality of managerial decisions (Lehn and Makhija, 1996) as well as a reliable indicator of a company's value growth in the future (Fisher, 1995).

Isa and Lo (2001) said that EVA has gained significant attention as alternative to traditional tools (as company valuation) for use in corporate performance and also can be used as incentive compensation plan. EVA measures have frequently been used in the determination of managerial compensation (Tortella, 2002). The purpose of EVA is to change the behaviour of management and their performance (Wileman, 1999) and lead managers to act more like owners (Tully, 1993). It can be used to motivate managers to create shareholder value by being a basis for management compensation (Stern et al.,1989).

\section{Performance of GLCs and non-GLCs}

Government-linked companies (GLCs) have played an important role in economic development especially in the developing nations. However, experience of many countries demonstrates that GLCs are usually less efficient than non-GLCs as measured by their economic performance. In countries where the share of GLCs is high, their typical low efficiency can hinder economic growth. It seems that these inefficiencies mainly result from the ownership effects and partly from lack of competition effects.

In non-GLCs their owners typically have the right to income stemming from the use of resources. The owners face directly the wealth effects according to the way in which the resources are used. However, GLCs can be expected to be concerned primarily with political (rather than economic) outcomes. Thus, the allocation of resources under GLCs is likely to be less efficient compared to non-GLCs. As stated in Boycko et al . (1996), politicians cause GLCs to employ excess labour input. GLCs may also be under pressure to hire politically connected people rather than professional managers from the market (Krueger, 1990). Besides, supervision by governments tends to be bureaucratic and rigid. The authorities tend to be more interested in seeing that regulations have been followed rather than that opportunities have been seized. In other words, unlike the non-GLCs which are mainly aimed to maximize their profit, the objectives of GLCs are more socially and politically inclined. 
In general, one of the main reasons why GLCs suffer from lower performance is that GLCs managers have little or no incentive to pursue profitability for their companies. Easy access to government-guaranteed loans lowers the risk of bankruptcy. Thus, proponents of privatization believed that privatization could improve the performances of companies. One view is that private ownership will improve monitoring, thus helping to solve the principle-agent problem that allows poor managerial performances and improves efficiency (Vickers and Yarrow, 1991). Delaying the process of privatization not only hurts efficiency but is also unfair because the monopolistic power and preferential treatments, such as obtaining cheap loans traditionally enjoyed by GLCs translate into discriminations against non-GLCs.

Performance of newly privatized firms in China has shown a significant improvement compared to the GLCs (Wei et al., 2003). La Porta et al. (2002) recorded that government ownership of banks around the world remained large in the 1990s. They conclude that resource allocation process being politicized in both government-owned companies and banks, thus reduces efficiency. Dewenter and Malatesta (2001) use large data set for GLCs and non-GLCs which are included in Fortune Magazine's Global 500 for 1975, 1985 and 1995. Their study indicates that GLCs are significantly less profitable than privately owned firms. Ahuja and Majumdar (1998) examine the performance of 68 Indian state-owned enterprises in the manufacturing sector from 1987 to 1991 . They conclude that the Indian state-owned firms are characterized by a low performance. Privatization and economic liberalization have managed to induce efficiency gains over time. There are numerous other studies which indicate that GLCs are less efficient compared to non-GLCs. Those studies include Megginson et al., (2004), Barth et al., (2000), Nellis (1994), Kumar (1993), and Broadman and Vining (1992).

However, on the contrary, the view that GLCs are inherently less efficient than non-GLCs may not be true in all cases. Vickers and Yarrow (1991) state that agency problems arise in both GLCs and non-GLCs. It is entirely possible that non-GLCs with major corporate governance problem may perform less than GLCs. Chang and Singh (1997) indicate that both GLCs and large non-GLCs are subject to bureaucracies, and non-GLCs may not necessarily perform better or have better governance. Based on the agency theory and the free rider problem, the government is the blockholder in GLCs and can monitor the managers of GLCs more intensely than shareholders of diffusely held private corporations monitor their managers (Dewenter and Malatesta, 1997).

An example where GLCs outperformed the non-GLCs can be seen in Singapore (Ang and Ding, 2006). Their study compares the financial and market performance of GLCs and non-GLCs and showed that GLCs in Singapore have better corporate governance and higher valuations compared to non-GLCs. Another study shows that privatization process does not necessarily improve the performance of the firms involved. Omran (2003) showed that Egyptian privatized firms do not exhibit significant improvement in performance compared with GLCs. One main reason why non-GLCs perform better than GLCs in general is because the goals of GLCs are different from the non-GLCs. Bozec et al. (2002) present empirical evidence that the GLCs, if their main goal is to maximize profit, can perform as well as the non-GLCs. 


\section{Data and Methodology}

Similar to many other developing nations, the GLCs play an important role in Malaysian economy. In 2005, the Malaysian government oversaw 57 listed GLCs, accounting for around 36 per cent of the total market capitalization of Bursa Malaysia. Even though the GLCs make up to only 5 per cent of the firms listed on Malaysia stock market, but the combined assets of these companies are approximately RM 261 billion, i.e. more than half of Malaysia GDP. PETRONAS, the oil and gas giant is the Malaysian largest company and it is wholly government-owned. The government has a majority equity stake in seven of the top ten listed companies, such as the Malaysian Airlines, Telekom Malaysia and Tenaga Nasional.

This study attempts to compare the performance of GLCs and non-GLCs in Malaysia using EVA as the performance measurement. Exploratory designs and correlational method have been chosen for this study.

\subsection{Data}

Data used in this study are limited to those of GLC listed company or limited (Berhad) company in Bursa Malaysia. The company must be active in the business and trades on Bursa Malaysia. The sample companies comprise of different industries and types of boards.

Historical or secondary data of company's financial statement are used to calculate EVA, EPS, DPS and NOPAT. The data are abstracted from the Profit and Lost Account, Balance Sheet and Financial Highlights, available from the PACAP DATABASE, available from PACAP Research Center. ${ }^{1}$ A legislative requirement wants all companies under Bursa Malaysia to submit audited financial statements every year to the Security Commission (SC), its supervisory commission. The daily share price of the companies is based on Bursa Malaysia trading closing price. This information is drawn from the Hydra System.

The judgment sampling for non-random sampling will be used instead of random sampling since judgment is used in selecting the sample. For this study all public listed companies in Bursa Malaysia, subject to its availability of information has been used.

Data from 37 GLCs (15.10 per cent) and 208 companies ( 84.90 per cent) non-GLCs over the period 1999-2002 were taken into consideration in the analysis. These companies are listed on Bursa Malaysia. These companies must be actively traded on Bursa Malaysia, and should not be classified as PN4 companies. They must have completed a full accounting period or 12 months business operation for each year and the accounting period must be consistent and have the same year-end throughout the 4 years period. Companies are also required to be listed during this study period.

1 PACAP Research Center, College of Business Administration, The University of Rhode Island Kingston, Rhode Island 02881-0802, U.S.A. 


\subsection{Methodology}

In this study, EVA is calculated based on Cordeiro and Kent Jr. (2001) which is as follows:

where

$$
\mathrm{EVA}=\text { NOPAT }-(\text { WACC X Invested Capital). }
$$

NOPAT $=$ Profit\&Loss before Tax + Interest Expense - Income Taxes - Tax

Shield on Interest (Tax Rate X Interest Expense)

and

Invested Capital $=$ Short Term Debt + Long Term Debt + Minority Interest + Shareholders Equity ${ }^{2}$

where

WACC $=$ Cost of Debt X $\{$ Total Debt $/($ Total Debt + CMVE $)\} X(1-$ Tax $)+$ $[\text { Cost of Equity X }\{(\mathrm{CMVE} /(\text { Total Debt }+ \text { CMVE }))\}]^{3}$ where where

$$
\text { CMVE }=\text { Company's Share Price X Total Shares Outstanding }
$$
where

Market Value of Company $=\mathrm{CMVE}+$ Total Debt + Minority Interest

Cost of Equity is calculated by using CAPM Model ${ }^{4}$

EVA is defined as the dollar amount of net operating profit after tax (NOPAT) minus the dollar charge for capital (both debt and equity) obtained by multiplying the percentage of weighted average cost of capital (WACC) (Cordeiro and Kent Jr., 2001). EVA it is an estimate of the amount by which earnings exceed or fall short of the rate of return shareholders and lenders could get by investing in other securities of comparable risk and includes a charge against profit for the cost of all the capital a company employs. Isa and Lo (2001), Stewart (1990), Lehn and Makhija (1996), Uyemura et al. (1996), Milunovich and Tsuei (1996), Grant (1996) and Turvey et al. (2000) carried out on what might be of superior metrics on evaluating firm performance, i.e. either EVA or conventional measures. They had used EVA as the independent variable in their study. In this study, EVA per share is treated as a dependent variable.

Companies are classified as government-owned when there is a minimum ownership of 20 per cent by a government entity or government investment vehicles. Such classification is based on research by Cormier and Magnan (2003) and Eng and Mak (2003) that used a dichotomous identifier as 1 for companies with 20 per cent government holdings, and 0 for companies with non-government holdings.

2 All the above items are based on the financial statements in the annual report of each company for the year 1999-2002.

$3 \mathrm{WACC}=\mathrm{CD} X\{\mathrm{TD} /(\mathrm{TD}+\mathrm{CMVE})\} \mathrm{X}(1-\mathrm{T})+[\mathrm{CE} \mathrm{X}\{(\mathrm{CMVE} / \mathrm{TD}+\mathrm{CMVE})\}]$

4 CAPM Model, equal Risk Free Rate + Beta (Market Return - Risk Free Rate) or Risk Free Rate + Company's Risk Premium or Risk Free Rate + (Company's Beta X Market Risk Premium). 
To test the hypothesis, the panel pool single and multiple regression with common and period specific coefficients least squares analysis with White's heteroskedasticity-consistent (corrected) variances and standard errors are used.

White (1980) has derived a heteroskedasticity consistent covariance matrix estimator which provides correct estimates of the coefficient covariances in the presence of heteroskedasticity of unknown form. The White covariance matrix is given by:

$$
\hat{\sum} w=\frac{T}{T-k}\left(X^{\prime} X\right)^{-1}\left(\sum_{t=1}^{T} u_{t}^{2} x_{t} x_{t}^{\prime}\right)\left(X^{\prime} X\right)^{-1}
$$

where is $T$ the number of observations, $k$ is the number of regressors, and $U_{t}$ is the least squares residual.

The panel pool regression with common coefficients means that for one period of study, all the different years have the same value or common coefficient. In turn, for panel pool regression for period specific coefficients, the value of coefficients are different for each year even for the same one period of study, it has period specific coefficients. For this study both technique was used in studying the ability of performance tools when explaining the dependent variable (company performance or stock return).

The panel data regression assumes that slope coefficients are constant but the intercept varies across individuals. It assumes that time or yearly slopes are constant but companies intercept vary across each company. Statistical inference is conditional on the observed cross-sectional units in the sample (Gujarati, 2003). This process is called the fixed effects model (fem) and it is widely used among econometricians as the best assumption when sample number is large and period of study is shorter.

\section{Results and Analysis}

Analysis involves panel pool regression analysis with common and period specific coefficients with White's heteroscedasticity-corrected variances and standard errors analysis.

\subsection{Descriptive Analysis}

The panel pool least squares analysis for main board listed companies extends over the period 1999 to 2002 and involves a total 245 companies. Thus, the panel pool regression analysis covers 980 observations over a period of four (4) years.

The distribution of the sample companies is cited in Table 1 on the following page.

Out of the 37 GLCs, 35 companies (94.59 per cent) were institutionally owned, while only 2 companies ( 5.41 per cent) were individually owned. Thus, it is apparent that companies with foreign or government stakeholders are more inclined towards an institutional type ownership when making an investment. Nine companies (24.32 per cent) of the 37 GLCs are in diversified business activities while 28 companies (75.68 per cent) were in non-diversified business activities. It can be concluded that companies with government as stakeholders are more inclined towards having concentrated core business activities instead of diversified business activities. 
Table 1

List of Sample Companies Based on Type of Industry for 245 Companies

\begin{tabular}{|l|r|c|}
\hline INDUSTRIAL PRODUCT & 61 & $24.90 \%$ \\
\hline HOTEL & 4 & $1.63 \%$ \\
\hline TRADING AND SERVICES & 58 & $23.67 \%$ \\
\hline PROPERTIES & 45 & $18.37 \%$ \\
\hline PLANTATION & 21 & $8.57 \%$ \\
\hline MINING & 2 & $0.82 \%$ \\
\hline CONSUMER PRODUCT & 30 & $12.24 \%$ \\
\hline CONSTRUCTION & 19 & $7.76 \%$ \\
\hline TECHNOLOGIES & 5 & $2.04 \%$ \\
\hline TOTAL & 245 & $100.00 \%$ \\
\hline
\end{tabular}

It concludes that companies in Malaysia with government stakeholders prefer an institutional type ownership when making an investment. Furthermore, the companies with government stakeholders also prefer concentrated or core business activities to diversified business activities. It is also found that companies with government stakeholders have higher degrees of concentrated business compared to companies in which both of the parties were not their stakeholders.

\subsection{Findings}

As shown in Table 2, the EVA values of the Malaysian companies are significantly related to the size of the companies (SIZE), whether they are government-linked (GOVERNMENT), foreign-owned (FOREIGN) and involved in diversification (DIVERSIFICATION). However, leverage (LEVERAGE) and types of ownership (TYPE OWNERSHIP) were found not to be significantly related to the EVA values of the companies.

The outcome of this study indicates a negative relationship between the size of the companies and the EVA values, that is, larger companies tend to have lower EVA values. In Malaysia, the GLCs are generally larger in size as compared to non-GLCs. Whether the companies are government-linked or not is also an important factor that could determine the companies' values. Our results contradict the study carried out in Singapore (Ang \& Ding, 2006) where GLCs were found to provide superior returns (on both assets and equity) on average, and were valued more highly given their better management of expenses than non-GLCs. That study also indicates that GLCs in Singapore are generally associated with better governance practices. However, in Malaysia, companies with government as their stakeholders tend to exhibit lower EVA scores than the companies without government stakeholders. The EVA values of average GLCs in Malaysia are less than of the non-GLCs by RM-73,532,007 (based on coefficient scores). Such finding tends to be contrary to the idea that companies with government holdings tend to have better corporate governance practices and are better monitored. It is believed that the Malaysian government prefers investing in public amenities companies to protect public interest, as witnessed by their active role in Telekom, POS and TNB. These types of companies do not have higher value than their counterparts, where the latter are usually profit-oriented organization. 
Foreign-owned companies also tend to have higher EVA values compared to locally-owned companies. Our study also shows that diversification reduces the company's values.

Table 2

Panel Pool Regressions with Common Coefficients between GLCs and EVA

\begin{tabular}{|l|c|c|c|c|}
\hline \multicolumn{5}{|c|}{ Dependent Variable: EVA } \\
\hline Variable & Coefficient & Std. Error & t-value & Prob. \\
\hline SIZE & -0.045877 & 0.003101 & -14.79300 & 0.0000 \\
\hline LEVERAGE & -653556.0 & 718529.0 & -0.909575 & 0.3633 \\
\hline FOREIGN & $1.00 \mathrm{E}+08$ & 31351096 & 3.197327 & 0.0014 \\
\hline GOVERNMENT & -73532007 & 34103171 & -2.156163 & 0.0313 \\
\hline DIVERSIFICATION & -60810425 & 25117273 & -2.421060 & 0.0157 \\
\hline TYPE OWNERSHIP & -38689066 & 28906623 & -1.338415 & 0.1811 \\
\hline CONSTANT & -17208963 & 26789187 & -0.642385 & 0.5208 \\
\hline R-squared & 0.223684 & F-statistic & 46.72597 \\
\hline Adjusted R-squared & 0.218897 & Prob(F-statistic) & 0.000000 \\
\hline
\end{tabular}

The model in Table 3 includes GOVERNMENT*SIZE as an interaction term. The inclusion of this term has caused the individual role played by SIZE and GOVERNMENT to be non-significant whereas the interaction term GOVERNMENT*SIZE becomes strongly related to the EVA values. This outcome further emphasizes that companies that have both the characteristics, large sized and government-linked, tend to have lower EVA values. As shown in Table 3, the size of GLCs is negatively correlated with the EVA. The coefficient of -0.078243 , indicates that any increment in size of the company for GLCs will decrease or destroy the value of the company, and to a greater degree, than companies without government holding. This can also be interpreted as an expansion in the size of government holding companies could lead to a greater proportion in capital cost increment compared to the returns generated.

Table 3

Panel Pool Regressions which Include Interaction Term GOVERNMENT* SIZE

\begin{tabular}{|l|c|c|c|c|}
\hline \multicolumn{5}{|c|}{ Dependent Variable: EVA } \\
\hline Variable & Coefficient & Std. Error & t-value & Prob. \\
\hline SIZE & -0.001923 & 0.004226 & -0.454978 & 0.6492 \\
\hline LEVERAGE & -656257.7 & 657669.2 & -0.997854 & 0.3186 \\
\hline GOVERNMENT & 47478658 & 32033575 & 1.482153 & 0.1386 \\
\hline FOREIGN & 46213448 & 28584036 & 1.616757 & 0.1063 \\
\hline GOVERNMENT* SIZE & -0.078243 & 0.005668 & -13.80461 & 0.0000 \\
\hline TYPE OWNERSHIP & -33714979 & 26102241 & -1.291651 & 0.1968 \\
\hline DIVERSIFICATION & -66840283 & 22684037 & -2.946578 & 0.0033 \\
\hline CONSTANT & -34683889 & 24221403 & -1.431952 & 0.1525 \\
\hline R-squared & 0.354048 & F-statistic & 76.10799 \\
\hline Adjusted R-squared & 0.349396 & Prob(F-statistic) & 0.000000 \\
\hline
\end{tabular}




\section{Conclusion}

In Malaysia, companies with government as their stakeholders have lower values of EVA than the companies without government stakeholders. The Malaysian government invests in companies, such as Telekom, POS and TNB, to protect public interest and bails out certain companies that represent the image of the country, such as Proton, Perwaja and DRB. These companies do not usually have high values in contrast to their competitors which are oriented on profit. Like most developing nations' experiences where GLCs are less efficient, GLCs performance in Malaysia is of no exception. This could partly result from the ownership effects and also from the lack of competition effects.

GLCs in Malaysia can be expected to be concerned primarily with political and social (rather than economic) outcomes. One major development agenda of the Malaysian government is to ensure more active participation of bumiputera (mainly ethnic Malays and other indigenous groups) in its economy activities. One of the policies includes requiring new listings on Bursa Malaysia to have an initial 30 per cent bumiputera equity ownership. Such policies could be restrictive to business activities and may cause the GLCs to under-perform.

Contrary to the non-GLCs, GLCs in Malaysia are more inclined to hiring politically connected people rather than professionals to manage the companies. GLCs managers also have less incentive to pursue profitability for their companies.

This study has also highlighted the size of company as an important factor that influences the EVA values. An increase in company size tends to have an adverse effect on the EVA values. Companies which are both large in size and government-owned, tend to suffer from lower EVA values. As mentioned earlier, GLCs in Malaysia only make up to 5 per cent of listed firms in the Malaysian stock market but these companies accounted for about 36 per cent of the total market capitalization of Bursa Malaysia. This indicates that most of the GLCs are larger in size compared to the non GLCs. Evidence has also shown that an increase in the size of Malaysian companies with government as stakeholders tends to destroy company values (Ismail, 2006).

However, attempts have been made to restructure GLCs and revive under-performing GLCs. The restructuring of Khazanah Nasional Bhd, the government's investment arm, will adopt a more focused and market-oriented business strategy. The changes include restructuring and reducing the size of Khazanah's board and the bringing in of new professional managers to run the GLCs.

The outcomes of this study indicate that companies with government as the stakeholders fail to correlate and have negative relationship with EVA. Companies which have negative EVA illustrate the failure to provide higher returns than the cost of capital, thus, the government should avoid investing in such companies. On the other hand, the government should be directing their investment vehicles into value creator or companies with positive EVA values.

EVA can serve as a useful tool for the government-linked companies (GLC) or companies with government as stakeholders in their efforts to identify potential companies that they can invest in. This tool can be applied to calculate the pure profit of the companies after deducting the cost of capital (value of the company). As such, in addition to good corporate governance practices the government should be directing 
investment into higher return activities that exhibit positive EVA values. We believe that if the GLCs can successfully gear their investments to more efficient source, the companies' value can be significantly improved.

\section{References}

Ahuja, G., Majumdar, S. K. (1998), "An Assessment of the Performance of Indian State-Owned Enterprises". Journal of Productivity Analysis. 9 (2), pp. 113-132.

Ang, J. S., Ding, D. K. (2006), "Government Ownership and the Performance of Government-Linked Companies: The Case of Singapore“. Journal of Multinational Financial Management, 16, pp. 64-88.

Armitage, H. M., Wong, E., Douglas, A. (2001), "The Pursuit of Value“. CMA Management, 77 (7), pp. 34-38.

Barth, J. R., Caprio, J. G., Levine, R. (2000), "Banking Systems around the Globe: Do Regulation and Ownership Affect Performance and Stability?" University of Minnesota, Working Paper.

Berry, J. (2003), "ROI Guide: Economic Value Added". Internet Week, February, 2003.

Boardman, A. E., Vining, A. R. (1992), "Ownership vs. Competition: Efficiency in Public Enterprise". Public Choice, 73 (2).

Booth, R. (1997), "Economic Value Added as a Management Incentive". Management Accounting, October 1997.

Boycko, M., Shleifer, A., Vishny, R. W. (1996), "A Theory of Privatization". Economic Journal, 106 (435), pp. 309-319.

Bozec, R., Breton, G., Cote, L. (2002), "The Performance of State-Owned Enterprises Revisited". Financial Accountability and Management, 18, pp. 333-407.

Brewer, P. C., Chandra, G., Hock, C. A. (1999), "Economic Value Added, (EVA $\left.{ }^{\mathrm{TM}}\right)$ : Its Uses and Limitations". S.A.M. Advanced Management Journal, Spring, pp. 4-11.

Burkette, G. D., Hedley, T. P. (1997), "The Truth About Economic Value Added". CPA Journal, 67 (7), pp. 46-49.

Chang, H., Singh, A. (1997), "Policy Arena: Can Large Firms Be Run Efficiently without Being Bureaucratic?" Journal of International Development, 9 (6), pp. 865-875.

Chen, S., Dodd, J. L. (2001), "Operating Income, Residual Income and EVA ${ }^{\mathrm{TM}}$ : Which Metric is More Value Relevant?' Journal of Managerial Issues, Spring, pp. 65-86.

Cormier, D., Magnan, M. (2003a), "Environmental Reporting Management: A Continental European Perspective". Journal of Accounting and Public Policy, 22, pp. 43-62.

Davidson, S. (2003), "Analysis Tools Help Improve Bank Performance and Value". Community Banker, February, pp. 48-50.

Drucker, P. (1995), "The Information Executives Truly Need". US: Harvard Business Review, 73 (1).

Eng, L. L., Mak, Y. T. (2003), "Corporate Governance and Voluntary Disclosure". Journal of Accounting and Public Policy, 22, pp. 325-345.

Epstein, M. J., Young, S. D. (1998), “Improving Corporate Environmental Performance through Economic Value Added". Environmental Quality Management, Summer, pp. 1-7.

Fisher, A. B. (1995), "Creating Stockholder Wealth". Fortune, 132 (12), pp. 105-116.

Grant, J. L. (1996), "Foundations of EVA for Investment Managers". Journal of Portfolios Management, 23 (1), pp. 41-48.

Herzberg, M. M. (1998), “Implementing EBO/EVA® Analysis in Stock Selection”. Journal of Investing, pp. $45-53$.

Ismail, I. (2006), "Economic Value Added (EVA): Its Usefulness in Predicting Company Performance in Malaysia". Unpublished PhD's Thesis. Faculty of Business and Accounting, University of Malaya, Kuala Lumpur.

Johnson, R., Soenen, L. (2003), "Indicators of Successful Companies". European Management, 21 (3).

Krueger, A. O. (1990), "Government Failures in Development". Journal of Economic Perspectives, 4(3), pp. 9-23

Kudla, R. J., Arendt, D. A. (2000), “Making EVA ${ }^{\mathrm{TM}}$ Work”. AFP Exchange, 20 (4). 
Kumar, A. (1993), State Holding Companies and Public Enterprises in Transition. New York: St Martin's Press.

Lehn, K., Makhija, A. K. (1996), "EVA and MVA as Performance Measures and Signals for Strategic Change". Strategy and Leadership, 24, pp. 34-38.

McClenahen, J. S. (1998), "Accounting for Change". Industry Week, 247 (17), Iw, 09/21/98.

Megginson, W. L., Nash, R. C., Netter, J. M., Poulsen, A. B. (2004), "The Choice of Private versus Public Capital Markets: Evidence from Privatizations". Journal of Finance, 59, pp. 2835-2870.

Milunovich, S., Tsuei, A. (1996), "EVA in the Computer Industry". Journal of Applied Corporate Finance, 9 (1), Spring, pp. 104-115.

Nellis, J. (1994), "Is Privatization Necessary?" World Bank Viewpoint 17.

Omran, M. (2003), "The Performance of State-Owned Enterprises and Newly Privatized Firms: Empirical Evidence from Egypt". Global Development Network (GDN).

Stern, J. M., Stewart, G. B., Chew, D. H. (1989), Corporate Restructuring and Executive Compensation. Cambridge, MA: Ballinger Publishing Company.

Stewart, G. B. (1994), "EVA: Fact and Fantasy". Journal of Applied Corporate Finance, 7 (20), pp. $71-84$.

Taub, S. (2003), "MVPs of MVA". CFO Magazine, July.

Tully, S. (1993), The Real Key to Creating Wealth. New York: Fortune.

Turvey, C. G., Lake, L., Van Duren, E., Sparling, D. (2000), "The Relationship between Economic Value Added and the Stock Market Performance of Agribusiness Firm". Agribusiness, 16 (4), Autumn, pp. 399-416.

Uyemura, D. G., Kantor, C. C., Petit, J. M. (1996), "EVA for Banks: Value Creation, Risk Management, and Profitability Measurement". Journal of Applied Corporate Finance, 9 (2), pp. 94-111. 